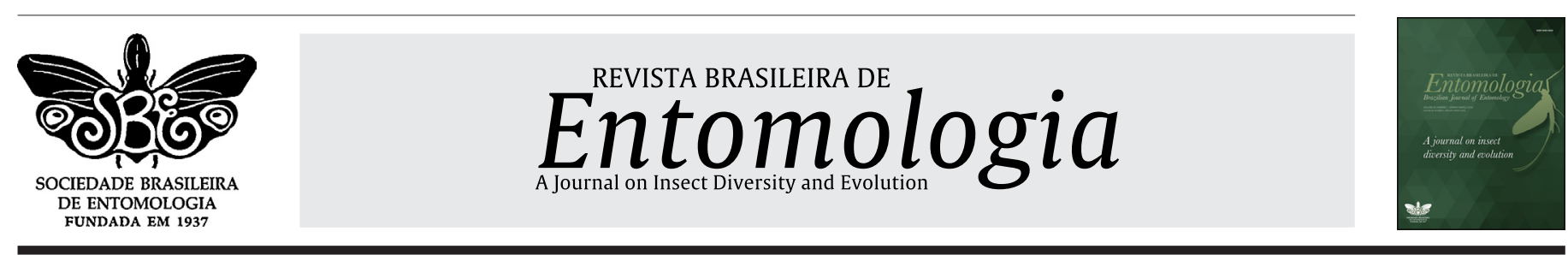

\title{
Resistance of cassava genotypes to Vatiga manihotae (Drake 1922) (Hemiptera: Tingidae)
}

\author{
Ana Paula Gonçalves da Silva Wengratt* (D), Diandro Ricardo Barilli² (D), \\ Daliana Hisako Uemura-Lima ${ }^{3}$ (D), Diego Gazola ${ }^{4}$ D, \\ Ana Tereza Bittencourt Guimarães ${ }^{5}$ (D) , Vanda Pietrowski $^{3}$
}

\author{
${ }^{1}$ Universidade de São Paulo, Escola Superior de Agricultura “Luiz de Queiroz" (ESALQ), Programa de Pós-graduação em Entomologia e \\ Acarologia, Piracicaba, SP, Brasil. \\ ¿Universidade Estadual Paulista “Júlio de Mesquita Filho", Jaboticabal, SP, Brasil. \\ ${ }^{3}$ Universidade Estadual do Oeste do Paraná, Marechal Cândido Rondon, PR, Brasil. \\ ${ }^{4}$ Universidade Estadual de Londrina, Londrina, PR, Brasil. \\ ${ }^{5}$ Universidade Estadual do Oeste do Paraná, Cascavel, PR, Brasil.
}

\section{A R T I C L E I N F O}

\section{Article history:}

Received 27 February 2020

Accepted 26 August 2020

Available online 25 September 2020

Associate Editor: Adeney Bueno

\section{Keywords:}

Cassava pests

Lace bug

Varietal resistance

Biological parameters

Fertility life table

\begin{abstract}
A B S T R A C T
Vatiga manihotae (Drake 1922) (Hemiptera: Tingidae) is an important cassava pest due to the great potential damage and the increasing population in recent years. However, few studies about bioecology and control of the cassava lace bug have been conducted and their results don't provide adequate control strategies. An alternative to maintain the population below economic injury levels is through the adoption of host plant resistance. To improve the understanding about the bioecology and find new sources of resistance in cassava, the biological parameters and demographics of $V$. manihotae on five cassava genotypes (Santa Helena, MEcu 72, Col 22, Clone 02 and Clone 03$)$ under controlled conditions $\left(25 \pm 2^{\circ} \mathrm{C}, 14 \mathrm{~L} / 10 \mathrm{D}\right)$ were evaluated. Duration and viability of the stages, the period egg-adult, sex ratio, the pre-oviposition period, fecundity and longevity of male and female was determined, and a fertility life table was prepared. Insects fed on MEcu 72 showed increased nymphal, egg-adult, and pre-oviposition periods and reduced female fecundity and longevity in comparison to the other genotypes. Demographic parameters (Ro, $r_{m}, T, D T$ ) showed a significant impact on the growth potential of V. manihotae fed on MEcu 72 indicating that the populations would diminish over time. The combined effect of these parameters indicated that MEcu 72 has resistance on $V$. manihotae specimens hindering their development.
\end{abstract}

\section{Introduction}

Cassava production plays an important socioeconomic role, with crops concentrated in areas belonging to small producers, that are characterized by the use of few inputs and low levels of technology. Additionally, it is used as raw material in many industrial processes (Carvalho and Fukuda, 2006).

An estimated 200 species of arthropods are associated with cassava, which in high populations can cause economic damage (Bellotti et al., 1999). Several species are specific to cassava and adapted in varying degrees to the natural biochemical defenses of the plant. In Southeastern Brazil, the cassava lace bugs Vatiga manihotae(Drake 1922) and V.illudens (Drake 1922)(Hemiptera: Tingidae) are important cassava pests and are worrying the productive sector of cassava due

\footnotetext{
* Corresponding author.

E-mail: anawengrat@gmail.com (A.P.G.S. Wengrat).
}

to the population increase and potential damage (Bellon et al., 2012; Pietrowski et al., 2010).

These species of Vatiga have shown preference to feed on cassava and both nymphs and adults can cause damage to the plants (Bellotti et al., 2002). The adults are grayish brown, measuring approximately $3 \mathrm{~mm}$ (Froeschner, 1993). The nymphs are whitish and approximately 0.65 to $2.3 \mathrm{~mm}$ long depending on the nymphal period (Wengrat et al., 2015). Initially the lace bug populate the undersides of basal and middle leaves of the cassava, but at high population it can infest the apical leaves, being favored by dry periods (Bellotti et al., 2012; Pietrowski et al., 2010). Lace bugs can cause damage by feeding on the cell protoplast from the leaf parenchyma, leaving chlorotic points, which can evolve to brown-reddish shades (Farias and Alves, 2004). These injuries decrease the photosynthetic index, cause defoliation and, in severe attack, the complete plant defoliation (Farias and Alves, 
2004; Pietrowski et al., 2010). These damages may cause reduction up to $55 \%$ in root productivity (Fialho et al., 2009).

For these species of Vatiga there are a lack of knowledge about the bioecology and level of damage, which become difficult the establish strategies to control them (Farias and Alves, 2004; Oliveira et al., 2001b). The scarcity of chemical and biological products to control insect pests associated with cassava is one of the main problems faced by farmers. At the moment there is no chemical registered for Vatiga sp. in Brazil (Agrofit, 2018). However, few studies about bioecology and control of the cassava lace bug have been conducted and their results don't provide adequate control strategies. For management of cassava pests the strategies to control include mainly chemical and biological control and host plant resistance (HPR) (Bellotti et al., 2012). This last method of control may be a promising alternative to maintain population of lace bugs below economic injury levels, because of the ease of widespread use by farmers, allows other methods of control and is economically viable and environmentally friendly (Bellotti and Arias, 2001; Lara, 1991).

Some cassava genotypes have been showing resistance to certain species of pests, as is the case of MEcu 72 genotype (Bellotti et al., 2012) to Aleurotrachelus socialis Bondar, 1923 (Bellotti and Arias, 2001; Carabalí et al., 2010a; 2010b), Bemisia tuberculata Bondar, 1923 (Barilli et al., 2019) and B. tabaci (Gennadius, 1889) (Hemiptera: Aleyrodidae) (Omongo et al., 2012). These insects when fed on MEcu 72 genotype have shown an increase in the development period, increase in the nymphal mortality rates and decrease of nymphal size and adults fecundity. To $V$. illudens the MEcu 72 genotype showed deterrence for oviposition, however, there are no studies about the biological parameters of lace bugs on this genotype (Oliveira et al., 2016). To improve the understanding about the bioecology and find new sources of resistance in cassava, the biological parameters and the demographics of $V$. manihotae on five cassava genotypes under controlled conditions were evaluated.

\section{Material and methods}

Plants

We evaluated one widely cultivated genotype in the South-Central region of Brazil (Santa Helena), two landrace genotypes widely studied for resistance to pests (MEcu 72 and $\mathrm{Col} 22$ ) and two materials from the breeding cassava program of Embrapa Mandioca e Fruticultura (Clone 02 and Clone 33). The Clone 02 is the crossing between Santa Helena and MEcu 72, and the Clone 33 is the crossing between Santa Helena and Col 22. The plants were cultivated in the experimental field of the Estação de Cultivo Protegido e Controle Biológico Professor Dr. Mário César Lopes, at Unioeste in Marechal Cândido Rondon, Paraná, Brazil

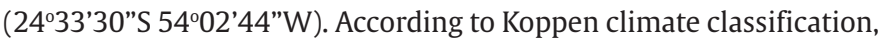
the regional climate is classified as type Cfa, subtropical, with average annual rainfall of $1,700 \mathrm{~mm}$ and yearly average temperature between $22^{\circ} \mathrm{C}$ and $23^{\circ} \mathrm{C}$ (Caviglione et al., 2000).

To insect rearing, cassava cutting $(10-15 \mathrm{~cm})$ of Baianinha genotypes were vertically fixed in 4 -L pots containing soil and $10 \%$ organic compost. The pots were watered twice a day. When there were eight fully developed leaves, the plants were transferred to a semi-acclimatized $\operatorname{room}\left(25 \pm 2^{\circ} \mathrm{C}, 14 \mathrm{~L} / 10 \mathrm{D}\right)$.

\section{Insect rearing}

Adults of $V$. manihotae were collected in a commercial agricultural area of cassava from the Baianinha genotype, from median and apical leaves, in the municipality of Marechal Cândido Rondon. In a stereomicroscope the adult were sexed, following the morphological parameters described by Drake (1922) and Froeschner (1993). Five couples per leaf were placed in four leaves per plant in ten plants of the Baianinha genotype. To hold the insects on the leaves we used leaf cages made with the fabric type voil (30 cm long x $25 \mathrm{~cm}$ width). The oviposition was allowed for $72 \mathrm{~h}$, after which the couples were removed. The leaves were monitored daily until nymph hatching to use in the study.

\section{Biological parameters}

Nymphs from the laboratory rearing were individually transferred to plastic boxes $(11 \times 11 \times 3.5 \mathrm{~cm})$ containing moistened filter paper and a leaf lobe from the different cassava genotypes testes. The leaves of each genotype were collected from plants grown at the experimental station in a field conditions without treatment against pests. In the laboratory, the leaves were sanitized for 30 minutes in a solution of $0.25 \%$ sodium hypochlorite, rinsed in distilled water and dried with absorbent paper. The leaves were inspected in a stereomicroscope for the presence of eggs of lace bugs that were removed. The base of each leaf lobe was covered with moistened cotton and lined with aluminum foil, in order to maintain the leaf turgidity. Fresh leaf lobes were renewed three to four times per week.

The nymphs were observed daily under a stereomicroscope, recording ecdysis and nymph mortality. With these observations were defined the number of instars, the duration and viability of each instar, the nymphal period and the egg-adult period. About 40 nymphs was initially evaluated in each genotype, each individualized nymph in each plastic box was a repetition.

After emergence, adults were sexed and the sex ratio was obtained. Seven couples were formed per genotype and maintained as described for nymphs. To MEcu 72 genotype, it was not possible to evaluate the seven couples, as there was a high mortality in the nymphal stage.

Every two days, new leaf lobes were provided and the amount of eggs deposited on the old leaf lobe were counted. Longevity of male and female, the pre-oviposition period, and fecundity were recorded to each couple. Leaf lobes containing ovipositions were kept until nymphys hatching in Petri dishes with agar at $2 \%$ in the bottom, to determine the duration of the egg stage and its viability.

\section{Fertility life table}

Following Silveira Neto et al. (1976) and Krebs (1994), a fertility life table was prepared from the biological data collected. The net reproductive rate (Ro), mean generation time $(\mathrm{T})$, intrinsic rate of increase $\left(\mathrm{r}_{\mathrm{m}}\right)$, and doubling time (DT) were calculated using the equations:

$$
\begin{aligned}
& R o=\sum l_{x} m_{x} \\
& T=\left(\sum l_{x} m_{x} x\right) /\left(\sum l_{x} m_{x}\right) \\
& r_{m}=\log R_{o} / T .0 .4343 \\
& D T=\ln (2) / r_{m}
\end{aligned}
$$

where $x$ is the age of the individual in days, $l_{x}$ the specific survival and $m_{x}$ the specific fertility. 
Index of adaptation

The adaptation index of $V$. manihotae to the different genotypes was calculated following the equation $\mathrm{IA}=\left(\mathrm{SBL}{ }^{*} \mathrm{FDA}\right) /(\mathrm{PDL})$, where, IA - index of adaptation, SBL- nymphal stage survival, FDA - adult fecundity, and PDL - period of nymphal development, adapted from Boregas et al. (2013).

\section{Statistical analysis}

The data obtained were tested for normality using the ShapiroWilk test and for homoscedasticity through the Cochran test. When necessary, data was $\log 10$ transformed for standardization. Variables in accordance with normality and homoscedasticity were subjected to ANOVA followed by Tukey's test to uneven sample sizes (HSD) $(p \leq 0.05)$. When the variables did not meet the statistical assumptions, the Kruskal-Wallis test followed Dunn's test were performed, using the software Statistica 7.0 (Statsoft Inc., 2004). The viability of the nymphal and egg-adult periods were tested through the $\chi 2$ test for $\mathrm{k}$ proportions.

Variables were evaluated through Principal Component Analyses (PCA) and the correlation between the arrays of variables was assessed by means of the Bartlett's Test of Sphericity. The number of principal components was defined by means of the Broken-Stick criterion. With the PCA it was possible to determine the explanatory variables for each individual assessed (Hair et al., 2006).

The parameters of the fertility life table were estimated by Jackknife technique, and the averages were compared using PROC GLM (SAS Institute, 2002), as described by Maia et al. (2000).

\section{Results}

Biological parameters

The average duration $\left(\mathrm{F}_{4,167}=7.15, p \leq 0.001\right)$ and viability $\left(\mathrm{H}_{4,1950}=28.03\right.$, $p \leq 0.001$ ) of the incubation period was affected by the cassava genotypes in which the insects were fed (Tables 1 and 2). Lace bugs fed on Clone 33 showed the shortest incubation period with significant difference in relation to insects fed on the others genotypes. Eggs from females fed on MEcu72 showed the highest viability than eggs from females fed on other genotypes, being $27.5 \%$ higher compared to Clone 02 (the lowest viability) (Table 2 ).

The duration of the first instar $\left(\mathrm{F}_{4,194}=2.41, p=0.050\right)$, fifth instar $\left(\mathrm{F}_{4,118}=6.40, p \leq 0.001\right)$, nymphal $\left(\mathrm{F} 4{ }_{, 118}=14.12, p \leq 0.001\right)$ and eggadult periods $\left(\mathrm{F}_{4,118}=21.37, p \leq 0.001\right)$ showed significant differences according to the cassava genotype (Table 1 ). There was no difference in the duration of the second $\left(\mathrm{F}_{4,175}=1.05, p=0.381\right)$, third $\left(\mathrm{F}_{4,146}=0.63\right.$, $p=0.642)$, and fourth instars $\left(\mathrm{F}_{4,129}=2.46, p=0.048\right)$. The genotype MEcu 72 interfered in the duration of the 5 th instar, increasing the nymphal period by approximately two days in comparison to other genotypes. Insects fed on MEcu 72 showed the longest duration of egg-adult period, approximately three days longer than insects fed on Clone 33 (the shortest duration).

The survival rate of all instars of $V$. manihotae $\left(1^{\mathrm{st}}: \mathrm{H}_{4,203}=3.88\right.$, $p=0.422 ; 2^{\text {nd. }}: \mathrm{H}_{4,199}=3.53, p=0.473 ; 3^{\text {rd }}: \mathrm{H}_{4,180}=1.38, p=0.848 ; 4^{\text {th }}: \mathrm{H}_{4,151}=8.14$, $\left.p=0.087 ; 5^{\text {th }}: H_{4,134}=7.84, p=0.098\right)$, as well as the nymphal $\left(\mathrm{H}_{4,203}=9.03\right.$, $p=0.060)$ and egg-adult periods $\left(\chi^{2}=2.05\right.$, d.f. $\left.=4, p=0.726\right)$ showed no significant differences (Table 2). Despite that, considering only the survival rate of the nymphal period, insects fed on MEcu 72 showed $32 \%$ lower survival rate than the insects raised on Clone 02 .

Table 1

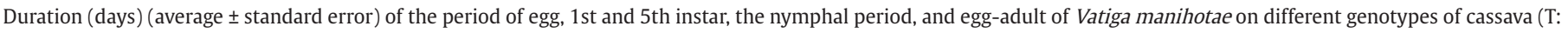
$25 \pm 2^{\circ} \mathrm{C}$; Photophase: 14 hours).

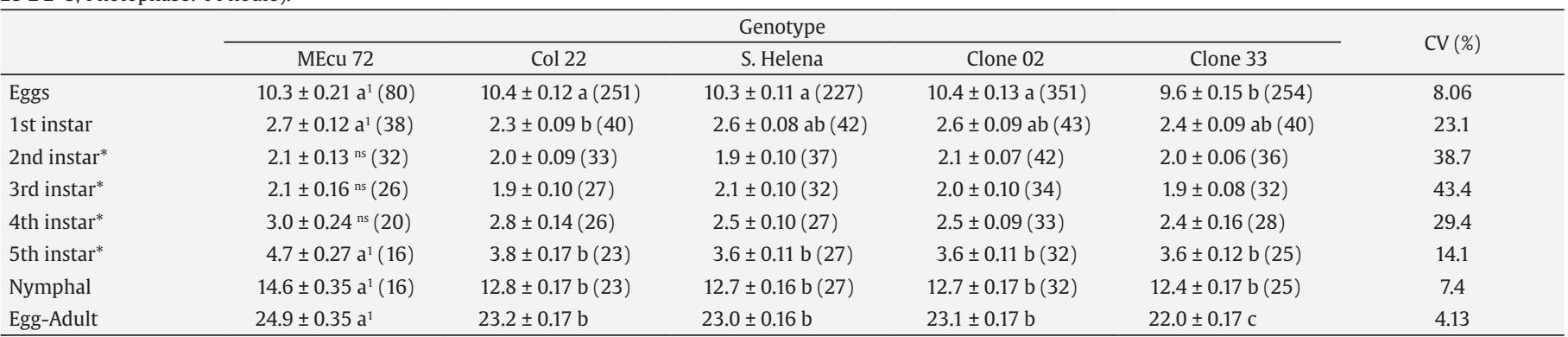

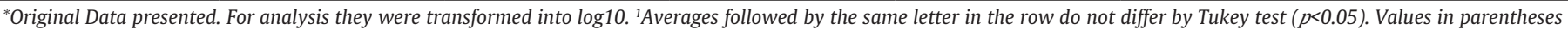
represent no. of insects or eggs.

Table 2

Viability (\%) of period of egg, 1 st to 5 th instar, the nymphal period, and egg-adult of Vatiga manihotae on different genotypes of cassava (T: $25 \pm 2{ }^{\circ} \mathrm{C}$; Photophase: 14 hours).

\begin{tabular}{|c|c|c|c|c|c|}
\hline & \multicolumn{5}{|c|}{ Genotype } \\
\hline & MEcu 72 & Col 22 & S. Helena & Clone 02 & Clone 33 \\
\hline Eggs & $83.3 a^{1}$ & $62.4 \mathrm{~b}$ & $58.2 \mathrm{~b}$ & $55.8 \mathrm{~b}$ & $58.7 \mathrm{~b}$ \\
\hline 1st instar & $94.7^{\mathrm{ns}}$ & 97.4 & 97.7 & 100.0 & 100.0 \\
\hline 2nd instar & $88.9^{\mathrm{ns}}$ & 86.9 & 88.1 & 97.7 & 90.0 \\
\hline 3rd instar & $81.3^{\text {ns }}$ & 81.8 & 86.5 & 80.9 & 88.9 \\
\hline 4th instar & $76.9^{\text {ns }}$ & 96.3 & 84.4 & 97.1 & 87.5 \\
\hline 5th instar & $80.0^{\mathrm{ns}}$ & 88.5 & 100.0 & 94.1 & 89.3 \\
\hline Nymphal & $42.1^{\mathrm{ns}}$ & 59.0 & 62.8 & 74.4 & 62.5 \\
\hline Egg-Adult & 35.1 ns & 36.8 & 36.5 & 41.5 & 36.7 \\
\hline
\end{tabular}

Averages followed by the same letter in the row do not differ by Kruskal-Wallis $(p \leq 0,05)$. 
The pre-oviposition period $\left(\mathrm{F}_{4,28}=7.35, p \leq 0.001\right)$, female longevity $\left(\mathrm{F}_{4,28}=3.60, p \leq 0.01\right)$ and fecundity $\left(\mathrm{F}_{4,28}=16.77, p \leq 0.001\right)$ showed significant differences according the genotype testes (Table 3 ). The male longevity was not significantly different among genotypes $\left(\mathrm{F}_{4,25}=0.82, p=0.524\right)$. Females raised on MEcu 72 had the longest pre-oviposition period, about eight days more to begin the oviposition than on the other genotypes, and the shortest longevity, 44 days less than females raised on Col 22 (The highest female longevity). The female fecundity was the lowest on MEcu 72 , showing $92 \%$ reduction of eggs laid when compared to those fed with Clone 02. Insects raised on the genotypes Santa Helena, Col 22, Clone 33 and Clone 02 showed no difference among themselves, with short pre-oviposition period and high longevity and fecundity. Insects fed on the Clone 33 yielded more females than males, whereas all the other clones showed increased male sex ratio.

Fertility life table

Vatiga manihotae raised on the five genotypes showed significant differences in Ro, $r_{m}, T$, and DT (Table 4). Specimens raised on MEcu 72 showed the lowest values of Ro, T, $r_{m}$ and DT in comparison to the other cassava genotypes. For the Ro, V. manihotae raised on MEcu 72 presented values $91 \%$ lower than specimens raised on the Clone 02. The T was approximately 18 days shorter for those specimens fed on MEcu 72 in comparison to the Clone 02 . The $r_{m}$ was about $52 \%$ less than insects fed on the Clone 33. The insects fed on MEcu 72 showed negative values for DT.

The pattern of oviposition of $V$. manihotae was strongly influenced by the cassava genotype (Figure 1). The females raised on MEcu 72 had no pronounced peak of oviposition, the average of eggs every two days were less than one, only on the $34^{\text {th }}$ day after emergence the females oviposited three eggs. The oviposition period of females raised on MEcu 72 and Clone 33 was the same, about 70 days, however, on Clone 33 the females oviposited between 6 to 8 eggs every two days. The females raised on Clone 02, Col 22 and Santa Helena showed the longest oviposition period, about 100 days, with average of oviposition between 3 to 5 eggs every two days.
The survival rate of females was different according to the genotype (Figure 1). The mortality of females raised on MEcu 72 began at $16^{\text {th }}$ day after emergence, on the $34^{\text {th }}$ day $50 \%$ of the females died. On the Clone 02 and Clone 33, the mortality began at the $20^{\text {th }}$ and $24^{\text {th }}$ day after emergence, respectively, however, $50 \%$ of the females died at $80^{\text {th }}$ day on Clone 02 and at $54^{\text {th }}$ day on Clone 33. The females raised on the $\mathrm{Col} 22$ the mortality began at the $42^{\text {th }}$ day and $50 \%$ of the females died at the $94^{\text {th }}$ day. For females raised on Santa Helena mortality began at day 54 , increasing rapidly and $50 \%$ of the females had died at day 76 .

\section{Principal component analysis (PCA)}

According the multivariate analysis of the data, we verified the cluster of the genotypes in two groups (Figure 2). The first axis of PCA represented $74.55 \%$ of the variation. This first canonical axis (F1) can be represented by the viability of nymphs, fecundity, longevity of females and males. The insects raised on Santa Helena, Col 22, Clone 02, and Clone 33 presented these factors in greater numbers and were located between the positive scores of this axis (to the right of the figure). Whereas MEcu 72 showed lower value relative to the variables analyzed, being located between the negative scores of this first axis.

\section{Index of adaptation}

The index of adaptation (IA) changed according to the genotype tested (Table 5). An index below one was observed for MEcu 72, this being $96 \%$ lower when compared with the higher index, which was shown by Clone 02. In MEcu 72, V. manihotae showed inferior biological parameters which indicates that this genotype is not suitable for $V$. manihotae development. The index of adaptation on Col 22 and Clone 33 showed intermediate values, being 40 and 44\%, respectively, smaller than the largest IA observed. In the genotype Santa Helena and Clone 02, the index of adaptation was higher, in these two materials the females showed higher fecundity, indicating that these genotypes favor the development of $V$. manihotae.

Table 3

Longevity (days) (average and standard error) of male and female, total fecundity (number of eggs), pre-oviposition period and sex ratio of Vatiga manihotae on different genotypes of cassava (T: $25 \pm 2^{\circ} \mathrm{C}$; Photophase: 14 hours).

\begin{tabular}{|c|c|c|c|c|c|}
\hline Genotype & Male Longevity & Female longevity & Fecundity* & Pre-oviposition & Sex ratio \\
\hline MEcu 72 & $37.3 \pm 23.33$ ns $(03)$ & $36.6 \pm 10.49 b^{1}(05)$ & $23.7 \pm 14.77 b^{1}(05)$ & $13.2 \pm 2.33 \mathrm{a}^{1}(05)$ & 0.47 \\
\hline Col 22 & $70.1 \pm 13.40(06)$ & $80.4 \pm 9.19$ a (07) & $226.6 \pm 27.84 \mathrm{a}(07)$ & $6.6 \pm 0.95 b(07)$ & 0.43 \\
\hline S. Helena & $71.8 \pm 12.35(07)$ & $76.4 \pm 7.53 \mathrm{ab}(07)$ & $265.3 \pm 45.84 \mathrm{a}(07)$ & $6.0 \pm 0.62 b(07)$ & 0.46 \\
\hline Clone 02 & $77.9 \pm 10.09(07)$ & $73.6 \pm 13.27 \mathrm{ab}(07)$ & $297.7 \pm 76.16$ a (07) & $5.0 \pm 0.68 \mathrm{~b}(07)$ & 0.37 \\
\hline Clone 33 & $72.4 \pm 14.46(07)$ & $48.3 \pm 7.13 \mathrm{ab}(07)$ & $193.1 \pm 35.79$ a (07) & $6.6 \pm 0.84 b(07)$ & 0.63 \\
\hline $\mathrm{CV}(\%)$ & 48.17 & 38.84 & 16.99 & 38.45 & - \\
\hline
\end{tabular}

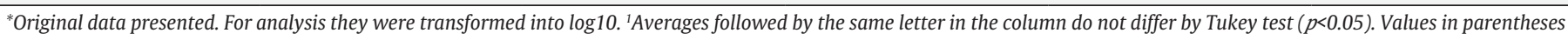
represent no. of insects

Table 4

Net reproduction rate (Ro), mean generation time (T), intrinsic rate of increase $\left(\mathrm{r}_{\mathrm{m}}\right)$, and doubling time (DT) of whitely, Vatiga manihotae raised on different genotypes of cassava (T: $25 \pm 2^{\circ} \mathrm{C}$; Photophase: 14 hours).

\begin{tabular}{|c|c|c|c|c|}
\hline Genotype & Ro (९/\%) & $\mathrm{T}$ (days) & $\mathrm{r}_{\mathrm{m}}$ (\%/\%/day) & DT(days) \\
\hline MEcu 72 & $3.89(-1.81-9.60) b^{1}$ & $35.0(29.2-40.9) c^{1}$ & $0.044(-0.012-0.101) c^{1}$ & $-0.34(-65.99-65.31) c^{1}$ \\
\hline Col 22 & $36.05(25.21-46.88) a$ & $53.2(43.4-63.1) \mathrm{a}$ & $0.067(0.056-0.079) b$ & $10.3(8.53-12.02) a$ \\
\hline S. Helena & $45.15(26.06-64.24) a$ & $47.2(41.2-53.2) a b$ & $0.080(0.065-0.096) a b$ & $8.5(6.90-10.16) a b$ \\
\hline Clone 02 & $46.26(17.30-75.22) \mathrm{a}$ & $52.7(45.4-59.9) \mathrm{a}$ & $0.073(0.064-0.082) b$ & $9.4(8.26-10.57)$ a \\
\hline Clone 33 & $45.02(24.61-65.43) \mathrm{a}$ & $41.4(35.7-47.1) b$ & $0.092(0.087-0.098) \mathrm{a}$ & $7.5(7.05-7.95) b$ \\
\hline
\end{tabular}

${ }^{1}$ Averages followed by the same letter in the column do not differ by the method of Jackniffe $(p \leq 0.05)$. Values in parentheses represent confidence interval (CI). 

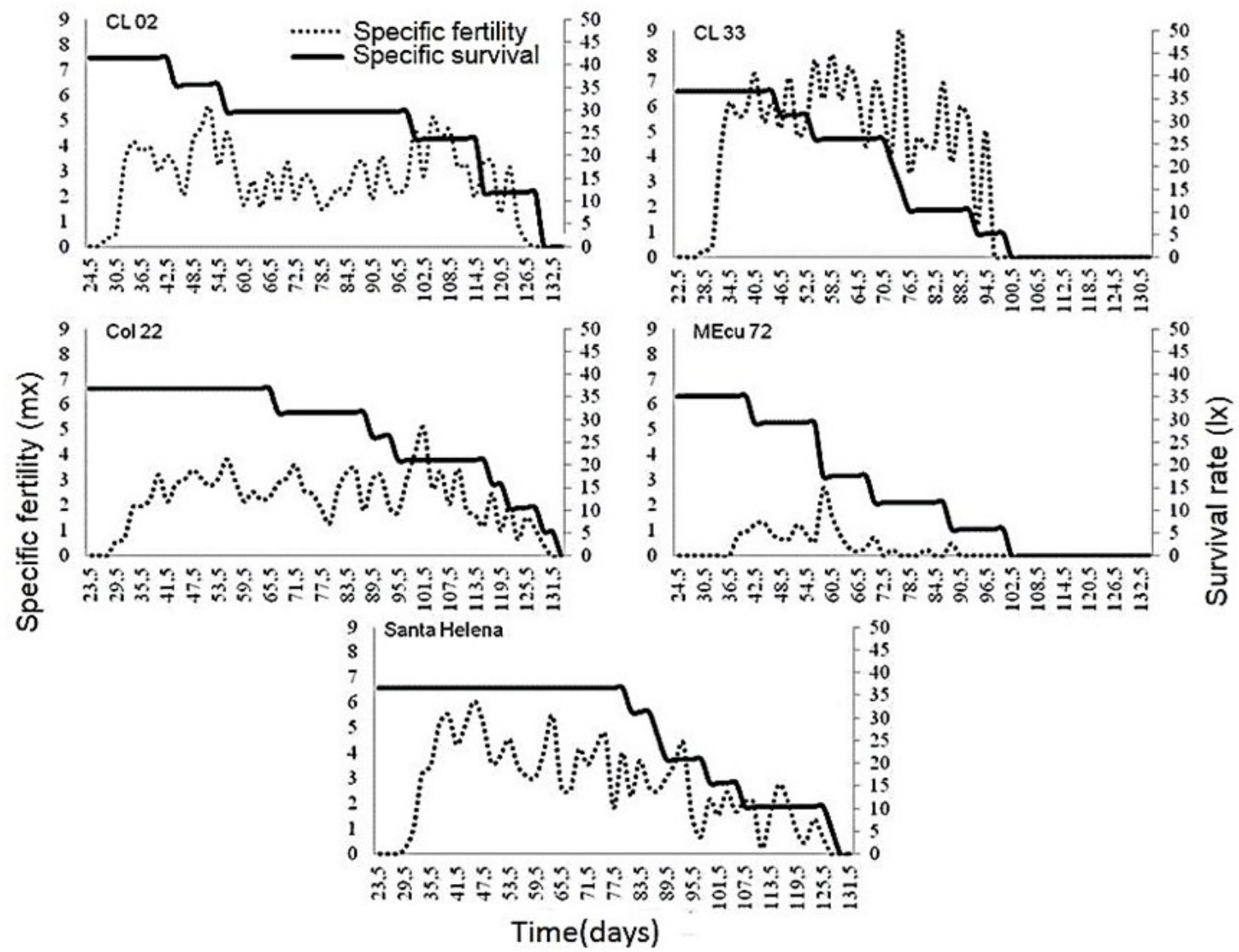

Figure 1 Relation between specific fertility $\left(\mathrm{m}_{\mathrm{x}}\right)$ and survival rate $\left(\mathrm{l}_{\mathrm{x}}\right)$ of Vatiga manihotae on five genotypes of cassava (T: $25 \pm 2^{\circ} \mathrm{C}$; Photophase: 14 hours).

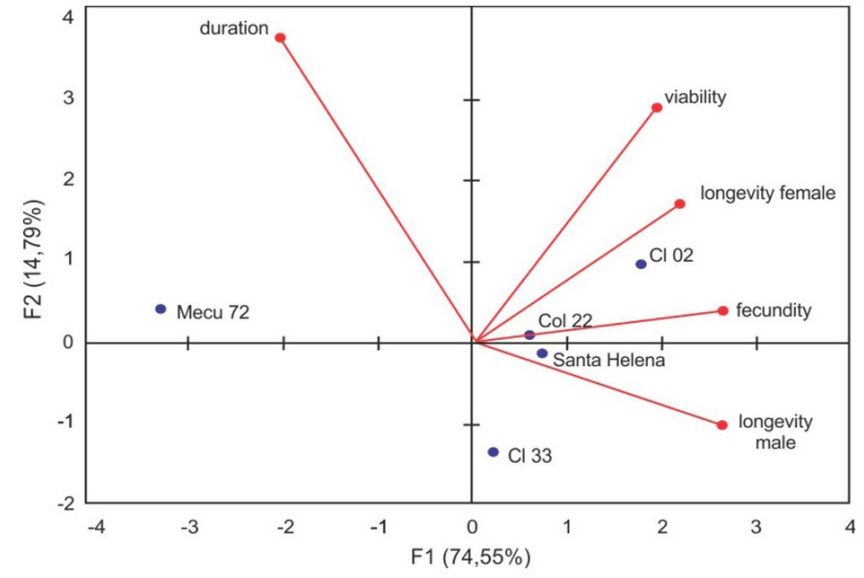

Figure 2 Ordination diagram representing the first axis of the principal components for the variables concerning the biology of Vatiga manihotae on different cassava genotypes. Genotypes: MEcu 72; Santa Helena; Col 22; Cl 02 Clone 02; Cl 33 Clone 33.

Table 5

Index of adaptation of Vatiga manihotae to different genotypes of cassava $\left(\mathrm{T} 25 \pm 2^{\circ} \mathrm{C}\right.$; Photophase: 14 hours).

\begin{tabular}{cc}
\hline Genotype & Adaptation Index \\
\hline MEcu 72 & 0.68 \\
Clone 33 & 9.73 \\
Col 22 & 10.44 \\
Santa Helena & 13.12 \\
Clone 02 & 17.44 \\
\hline
\end{tabular}

\section{Discussion}

Cassava shows several genes that confer resistance against insects, which can provide benefits such as to maintain the insect populations below the level of economic damage, to reduce yield losses and management costs, as well as may be exploited in integrated pest management (Bellotti et al., 1999). The mechanisms of cassava resistance to insects are polygenic and horizontal, and the genes that confer resistance are difficult to be transmitted to the progeny (Vendramim and Nishikawa, 2001). This type of resistance allows to control a wide spectrum of insects (Bellotti and Kawano, 1980). It is reported to MEcu 72 that present resistance against different species of whitefly, as $B$. tabaci biotype B (Omongo et al., 2012), A. socialis (Bellotti and Arias, 2001; Carabalí et al., 2010a; 2010b) and B. tuberculata (Barilli et al., 2019), which resulted in decrease of nymphal survival rate and reduced fecundity and longevity of adults.

Insects of $V$. manihotae fed on MEcu 72 showed increase of nymphal, egg-adult, and pre-oviposition periods and reduced fecundity and longevity of female in comparison to the other genotypes. However, the adults parameters were the most influenced by MEcu 72, especially in females, that need more suitable food for their reproductive performance (Parra 2009). Females delayed their oviposition period, to indicate longer periods for oocytes maturation and copulation (Awmack and Leather, 2002; Krüger et al., 2008), possibly due to requirement of supplement their nutritional reserves in the adult stage, as a consequence of inadequate supply in the nymphal period. In addition, the females started to die earliest resulting in lower longevity and fecundity on MEcu 72. 
With the fertility life table, it was possible to estimate the effects of genotypes in the insect population. Insects raised on MEcu 72 had great impact on growth the population, reflecting mainly on the doubling time. The DT showed negative value and large variance, indicating that the populations would diminish over time or take a long time (65,31 days) to doubling the population on this genotype. These results emphasize that MEcu 72 is not favorable for the development of $V$. manihotae.

These results to insects raised on MEcu 72 may be explained by the production of secondary compounds that interfere in the development and/or reproduction of the insects evidencing the presence of antibiosis (Bellotti and Arias, 2001; Carabalí et al., 2010a; Pinto-Zevallos et al., 2016). The secondary compounds act as a defense mechanism, and their concentrations usually changes according to the abiotic and biotic conditions (Bray et al. 2000; Gazola et al. 2018b). Secondary compounds comprize a series of chemical substances that may make the plant unsuitable for the development of insect, interfering in their survival, growth, fecundity and fertility (Bellotti and Arias, 2001; Ibanez et al., 2012).

Among the secondary compounds, the hydrocyanic acid may be associated with resistance to pests. For lace bugs, Cosenza et al. (1981) observed that lace bug infestations on cassava genotypes were related to levels of cyanogenic compounds in the plants. Sweet varieties (hydrocyanic acid of less than $100 \mathrm{ppm}$ ) were more infested than the bitter varieties (hydrocyanic acid above 100 ppm) by lace bugs (Fialho et al., 2009; Oliveira et al., 2001a). However, different genotypes presenting the same content of hydrocyanic acid showed different level of infestations (Vieira et al., 2011). According Rheinheimer (2013) MEcu 72 and Santa Helena presents similar concentration of cyanide. In this study, only MEcu 72 showed negative interference on the nymphal development. Cosenza et al. (1981) observed that some sweet genotypes presented more interference on the development resulting in lower number of adults. Thus, the cyanogenic compounds may more related on the infestation of lace bug than the development of these.

Other important secondary compounds related in cassava are rutin, cafeic, p-coumaric, ferulic and trace amounts of gallic acid (Calatayud et al., 1994; Gazola et al., 2018a). According Calatayud (2000) rutin plays an anti-nutritious and a phagodeterrent role affecting the development of the nymphs of Phenacoccus manihoti Matile-Ferrero (Hemiptera: Pseudococcidae). However, it is important to note that the rutin and other secondary compounds content varies according to the genotype and the conditions of cultivation, such as nitrogen fertilization (Gazola et al., 2018b). Polyphenol oxidases and peroxidases, other compounds associated with plant defense, are enzymes involved on the response of plants to attack of insects. The increase of these compounds in MEcu 72 by P. manihoti infestation was higher in comparison to Santa Helena (Rheinheimer, 2013). This may indicate that the activity of these enzymes may reduce the nutritional quality of the host, resulting in decreased nutritional supply and consequent reduction of fecundity to $V$. mahihotae. However, more studies about the composition and effects of the secondary compounds from these genotypes are needed.

Biological parameters of $V$. manihotae were similar on Santa Helena, Col 22, Clone 02 and Clone 33. In those four genotypes, greater viability of nymphs, fecundity, and longevity of females and males was observed, especially those fed with the genotypes Santa Helena and Clone 02. These genotypes effectively formed a distinct group of genotypes favorable to the development of $V$. manihotae, while MEcu 72 was isolated in the group with characteristics less favorable to the development of this species.

All these impacts of the MEcu 72 in the population of $V$. manihotae are expressed in the index of adaptation and the PCA. It is possible to point out that for this species, the genotype MEcu 72 is unsuitable for the development. Rheinheimer (2013) and Barilli et al., (2019), using biological parameters such as duration of nymphs, adults' longevity and fecundity, classified MEcu 72 as resistant to P. manihoti and $B$. tuberculata. Also according Barilli et al. (2019), Santa Helena was resistant to B. tuberculata and Rheinheimer (2013) classified Santa Helena as moderately resistant to $P$. manihoti. In the present study, this genotype has been shown susceptible to $V$. manihotae providing adequate development of the insect. This may be related to the fact that $P$. manihoti feeds on sap, whereas $V$. manihotae feeds from protoplasm.

Thus, according to the results obtained by several authors and by the biological parameters obtained here we infer that MEcu 72 shows be a possible source of resistance to $V$. manihotae, which could be used in cassava breeding programs. However, the genes that confer resistance to pests are polygenic (Bellotti and Kawano, 1980) and its transmission to other materials is difficult (Vendramim and Nishikawa, 2001), as occurred with the Clone 02 , which is crossings with MEcu 72, but do not show resistance to lace bugs. It is therefore recommended more crossings with this genotype with other productive materials, in order to combine resistance to $V$. manihotae and productivity.

\section{Acknowledgements}

This study was financed in part by the Coordenação de Aperfeiçoamento de Pessoal de Nível Superior - Brasil (CAPES) - Finance Code 001.

\section{Conflicts of interest}

The authors declare no conflicts of interest.

\section{Author contribution statement}

APGSW, DRB, DHUL and DG performed the bioassays and participated in all data collection. APGSW, DRB and ATBG performed the statistical analysis. APGSW, DRB, DHUL, DG and VP conceived and designed the research. APGSW, DRB, DG and VP interpreted data and wrote the paper. All authors read and approved the manuscript.

\section{References}

Agrofit, 2018. Sistemas de agrotóxicos fitossanitários. Ministério da Agricultura, Pecuária e Abastecimento, Brasília. Available in http:// agrofit.agricultura.gov.br/agrofit_cons/principal_agrofit_cons (accessed 27 February 2020).

Awmack, C. S., Leather, S. R., 2002. Host plant quality and fecundity in herbivorous insects. Annu. Rev. Entomol. 47, 817-844. https://doi. org/10.1146/annurev.ento.47.091201.145300.

Barilli, D. R., Wengrat, A. P. G. S., Guimarães, A. T. B., Pietrowski, V., Ringenberg, R., Garcia, M. S., 2019. Resistance of cassava genotypes to Bemisia tuberculata. Arthropod-Plant Interact. 14, 663-669. https://doi.org/10.1007/s11829-019-09694-z.

Bellon, P. P., Wengrat, A. P. G. S., Kassab, S. O., Pietrowski, V., Loureiro, E. S., 2012. Occurrence of lace bug Vatiga illudens and Vatiga manihotae (Hemiptera: Tingidae) in Mato Grosso do Sul, midwestern Brazil. An. Acad. Bras. Cienc. 84, 703-705. https://doi.org/10.1590/S000137652012000300012.

Bellotti, A. C., Campos, B. V. H., Hyman, G., 2012. Cassava production and pest management: present and potential threats in a changing environment. Trop. Plant Biol. 5, 39-72. https://doi.org/10.1007/ s12042-011-9091-4. 
Bellotti, A. C., Kawano, K., 1980. Breeding approaches in cassava. In: Maxwell F.G. and Jennings, P.R. (Eds.), Breeding Plants Resistant to Insects. John Wiley and Sons, New York, pp. 315-335.

Bellotti, A. C., Smith, L., Lapointe, S. L., 1999. Recent advances in cassava pest management. Annu. Rev. Entomol. 44, 343-370. https://doi. org/10.1146/annurev.ento.44.1.343.

Bellotti, A. C., Arias, B., 2001. Host plant resistance to whiteflies with emphasis on cassava as a case study. Crop Prot. 20, 813-823. https:// doi.org/10.1016/S0261-2194(01)00113-2.

Bellotti, A. C., Arias, V. B., Vargas, H. O., Reyes, Q. J. A., Guerreiro, J. M., Insectos y ácaros dañinos a la yuca y su control. In: Ospina, P., Ceballos, H., Alvarez, E., Bellotti, A.C., Calvert, L.A., Arias, V.B., Cadavid, L.F., Pineda, L., Benjamín, L. R., Germán, A., Cuervo, M.I. (Eds.), La yuca en el tercer milenio: sistemas de producción, procesamiento, utilización y comercialización. CIAT, Palmira, 2002. Chap.10. pp.160-203.

Boregas, K. G. B., Mendes, S. M., Waquil, J. M., Fernandes, G. W., 2013. Estádio de adaptação de Spodoptera frugiperda (J. E. Smith) (Lepidoptera: Noctuidae) em hospedeiros alternativos. Bragantia 72, 61-70. https://doi.org/10.1590/S0006-87052013000100009.

Bray, E. A., Bailey-Serres, J., Weretilnyk, E., 2000. Responses to abiotic stresses. In: Buchanan, B.B., Gruissen, W., Jones, L.R. (Eds.), Biochemistry and Molecular Biology of Plants. American Society of Plant Physiologists, New York, pp. 1158-1120.

Calatayud, P. A., 2000. Influence of linamarin and rutin on biological performances of Phenacoccus manihoti in artificial diets. Entomol. Exp. Appl. 26, 81-86. https://doi.org/10.1046/j.1570-7458.2000.00681.x.

Calatayud, P. A., Rahbe, Y., Delobel, B., Khuong-Huu, F., Tertuliano, M., Rü, B., 1994. Inluence of secondary compounds in the phloem sap of cassava on expression of antibiosis towards the mealybug Phenacoccus manihoti. Entomol. Exp. Appl. 72, 47-57. https://doi. org/10.1111/j.1570-7458.1994.tb01801.x.

Carabalí, A., Bellotti, A. C., Montoya-Lerma, J., Fregene, M., 2010a. Resistance to the whitefly, Aleurotrachelus socialis, in wild populations of cassava, Manihot tristis. J. Insect Sci. 10, 1-10. https:// doi.org/10.1673/031.010.14130.

Carabalí, A., Bellotti, A. C., Montoya-Lerma, J., Fregene, M., $2010 \mathrm{~b}$. Manihot flabellifolia Pohl, wild source of resistance to the whitefly Aleurotrachelus socialis Bondar (Hemiptera: aleyrodidae). Crop Prot. 29, 34-38. https://doi.org/10.1016/j.cropro.2009.08.014.

Caviglione, J. H., Kiihl, L. R. B., Caramori, P. H., Oliveira, D., 2000. Cartas climáticas do Paraná, IAPAR, Londrina.

Carvalho, P. C. L., Fukuda, W. M. G., 2006. Estrutura da planta e morfologia. In: Souza, L.S. (Eds.), Aspectos socioeconômicos e agronômicos da mandioca. EMBRAPA Mandioca e Fruticultura, Cruz das Almas, pp. 817.

Cosenza, G. W., Perim, S., Costal, I. R. S., 1981. Resistência de variedades de mandioca ao percevejo-de-renda, Vatiga illudens(Drake, 1922). Pesqui. Andamento 7, 1-6.

Drake, C. J., 1922. Neotropical Tingitidae with descriptions of three new genera and thirty-two new species and varieties (Hemiptera). Mem. Carnegie Mus. 9, 351-378.

Farias, A. R. N., Alves, R. T., 2004. O percevejo de renda na cultura da mandioca. EMBRAPA Mandioca e Fruticultura, Cruz das Almas. (Comunicado Técnico, 28).

Fialho, J. F., Vieira, E. A., Paula-Moraes, S. V. P., Silva, M. S., Junqueira, N. T. V., 2009. Danos causados por percevejo-de-renda na produção de parte aérea e raízes de mandioca. Sci. Agrár. Parana. 10, 151-155. https://doi.org/10.5380/rsa.v10i2.13587.

Froeschner, R. C., 1993. The neotropical lace bugs of the genus Vatiga (Heteroptera: tingidae), pests of cassava: new synonymies and key to species. Proc. Entomol. Soc. Wash. 95, 457-462.
Gazola, D., Zucareli, C., Ringenberg, R., Oliveira, M. C. N., Graça, J. P., Nunes, E. O., Hoffmann-Campo, C. B., 2018a. Secondary metabolite contents in different parts of cassava plants infested by Phenacoccus manihoti Matile-Ferrero (Hemiptera: pseudococcidae). Arthropod-Plant Interact. 13, 359-366. https://doi.org/10.1007/s11829-018-9649-2.

Gazola, D., Zucareli, C., Ringenberg, R., Graça, J. P., Hoffmann-Campo, C. B., 2018b. Nitrogen fertilization in the contents of secondary compounds in cassava cultivars. Semina: Ciênc. Agrár. 39, 10151028. https://doi.org/10.5433/1679-0359.2018v39n3p.

Hair, J. F., Black, W. C., Babin, B. J., Anderson, R. E., Tatham, R. L., 2006. Multivariate Data Analysis, 6th ed. Pearson Prentice Hall, New Jersey.

Ibanez, S., Gallet, C., Despres, L., 2012. Plant insecticidal toxins in ecological networks. Toxins (Basel) 4, 228-243. https://doi. org/10.3390/toxins4040228.

Krebs, C. J., 1994. Ecology: The Experimental Analysis of Distribution and Abundance. Harper \& Row, New York.

Krüger, R. F., Krolow, T. K., Azevedo, R. R., Duarte, J. L. P., Ribeiro, P. B., 2008. Sobrevivência e reprodução de Synthesiomyia nudiseta (Diptera, Muscidae). Iheringia Ser. Zool. 98, 45-49. https://doi. org/10.1590/S0073-47212008000100006.

Lara, F. M., 1991. Princípios de resistência de plantas a insetos. Ícone, São Paulo.

Maia, A. H. N., Luiz, A. J. B., Campanhola, C., 2000. Statistical inference on associated fertility life table parameters using Jackknife technique: computational aspects. J. Econ. Entomol. 93, 511-518. https://doi. org/10.1603/0022-0493-93.2.511.

Oliveira, M. A. S., Fialho, J. F., Alves, R. T., Oliveira, J. N. S., Gomes, A. C., 2001a. Dinâmica populacional do percevejo-de-renda (Vatiga illudens) na cultura da mandioca no Distrito Federal. Bol. Pesqui. Desenvolv. (Embrapa Cerrados) 3, 1-15.

Oliveira, M. A. S., Alves, R. T., Fialho, J. F., Junqueira, N. T. V., 2001 b. Patogenicidade de fungos entomógenos sobre o percevejo-de-renda da mandioca no Distrito Federal. Comun. Tecnico 45, 1-2.

Oliveira, H. N., Bellon, P. P., Loureiro, E. S., Mota, T. A., 2016. Não-preferência para a oviposição de percevejo-de-renda Vatiga illudens(Hemiptera: Tingidae) por cultivares de mandioca. Acta Biol. Colomb. 21, 447451. https://doi.org/10.15446/abc.v21n2.52021.

Omongo, C. A., Kawuki, R., Bellotti, A. C., Alicai, T., Baguma, Y., Maruthim, M. N., Bua, A., Colvin, J., 2012. African cassava whitefly, Bemisia tabaci, resistance in African and South American cassava genotypes. J. Integr. Agric. 11, 327-336. https://doi.org/10.1016/S2095-3119(12)60017-3.

Parra, J. R. P., 2009. Índices nutricionais para medir consumo e utilização de alimentos por insetos. In: Panizzi, A. R., Parra, J. R. P. (Eds.), Bioecologia e Nutrição de Insetos - Base para o Manejo Integrado de Pragas. EMBRAPA, Brasilia, DF, pp. 37-90.

Pietrowski, V., Ringenberg, R., Rhenheimer, A. R., Bellon, P. P., Gazola, D., Miranda, A. M., 2010. Insetos-praga da cultura da mandioca na região Centro-Sul do Brasil. UNIOESTE, Marechal Cândido Rondon. Available in: http://www.atividaderural.com.br/artigos/5602f5914fe45.pdf (accessed 27 February 2020).

Pinto-Zevallos, D. M., Pareja, M., Ambrogi, B. G., 2016. Current knowledge and future research perspectives on cassava (Manihot esculenta Crantz) chemical defenses: an agroecological view. Phytochemistry 130, 10-21. https://doi.org/10.1016/j.phytochem.2016.05.013.

Rheinheimer, A. R., 2013. Resistência de variedades de mandioca à cochonilha Phenacoccus manihoti Matile-Ferrero (Hemiptera: Pseudococcidae) e sua influência sobre o parasitoide Anagyrus Iopezi (De Santis). PhD Thesis, Universidade Estadual do Oeste do Paraná, Marechal Cândido Rondon, Brasil, 112 pp.

Silveira Neto, S., Nakano, O., Barbin, D., Villa Nova, N. A., 1976. Manual de ecologia dos insetos. São Paulo: Editora Agronômica Ceres. 
Statsoft Inc., 2004. STATISTICA (data analysis software system), version 7. Available in: www.statsoft.com (accessed 27 February 2020).

Vendramim, J. D., Nishikawa, M. A. N., 2001. Melhoramento para resistência a insetos. In: Nass, L.L., Valois, A.C.C., Melo, I.S., ValadaresInglis, M.C. (Eds.), Recursos genéticos e melhoramento. Fundação, Rondonópolis, pp. 737-781.

Vieira, E. A., Fialho, J. D. F., Faleiro, F. G., Bellon, G., Fonseca, K. G. D., Carvalho, L. J. C. B., 2011. Characterization of sweet cassava accessions based on molecular, quantitative and qualitative data. Crop Breed. Appl. Biotechnol. 3, 232-240. https://doi.org/10.1590/ S1984-70332011000300005.

Wengrat, A. P. G. S., Matesco, V. C., Barão, K. R., Grazia, J., Pietrowski, V., 2015. External morphology of the immature stages of Vatiga manihotae (Hemiptera: Tingidae) with comments on ontogenesis. Fla. Entomol. 98, 626-632. https:// doi.org/10.1653/024.098.0236. 